\title{
THE FUTURE OF SUNDANESE COMMENTARIES ON THE QUR'AN IN INDONESIAN ARCHIPELAGO
}

\author{
Jajang A Rohmana \\ State Islamic University (UIN) Sunan Gunung Djati Bandung \\ jajang_abata@yahoo.co.id
}

\begin{abstract}
This study highlights the opportunities and challenges of Qur'anic commentaries or tafsir in Sundanese. I will show that the position of Sundanese tafsir cannot be separated from cultural background and politics of regional languages in Indonesia, as well as shift of global information technology and literacy. The rise of publication of Sundanese tafsir would not only be influenced by the reformist Muslim commentary on the Qur'an in the Middle East at the beginning of the twentieth century but also the Dutch colonial policy on regional language that enhanced the print publication of Sundanese. Now, however, the publication of Sundanese tafsir is beginning to decline. There are many factors contributed to the decreasing publication of Sundanese tafsir, such as the assumptions of more complex rules of regional language, the government policy of national language and the invasion of global television networks and the evolution of the internet and social media. I worried about these factors could make the identity of Sundanese tafsir began to disappear. The identity of Sundanese tafsir related to its uniqueness in the richness of the language and locality of the tafsir issues. Its locality of the tafsir issues in Indonesia related to the transmission of 'Abduh's ideas about Islamic reform to Southeast Asia, as reflected in al-Manar. Instead of presumably asserting that the rise of publication of Sundanese tafsir related to the idea of Islamic reform to respond to the traditionalist Islamic thought. It was different from the contemporary approach to the study of the Qur'an that not yet used in the Sundanese tafsir along with the publication began to decline.
\end{abstract}

Keywords: The Qur'an, Sundanese tafsir, history, literacy

\section{Introduction}

The study of the Qur'ân in regional language in Indonesia became the subject many scholars paid attention to, much more than before. It can be seen from the increased study of scholars on the qur'anic commentaries in Javanese, Sundanese, Buginese, and others (Gusmian, 2016: 141-168; Rohmana, 2013; Ibrahim, 2012). It is not only related to hotly-debated religious issues on "Islam Nusantara," but also the discourse of Islamic studies, which were no longer dominated by Middle Eastern studies, but Europe, Asia and Southeast Asia (Sardar 1983: 197; Rafiq, 2014: 10).

However, in the midst of attention to the study of the Qur'ān in regional language in Indonesia, scholars faced the decline of qur'anic studies publication in regional language. In the context of qur'anic commentary in Sundanese, for example, there are about twenty publications of Sundanese tafsir in the period of the 1930s to the 1990s (Rohmana, 2013: 197-224). Now, however, only one or two new books of Sundanese tafsir were published. The last book was published about six years ago (Suhendar, 2011). Therefore, it is important to analyze the future of the Sundanese tafsir to maintain its local identity against the trend of global scholarship on the Qur'ān in Indonesia.

In this study, I attempt to identify the various strengths, weaknesses, opportunities, and threats were faced by the discourse on Sundanese tafsir today, 
using social history analysis (Stearns ed., 1994: 608). It was chosen because of the Sundanese as the second majority of the Indonesian population after Javanese with nearly thirty-one million people (Suryadinata, 2003: 7). It also related to the number of publication of Sundanese tafsir $\mathrm{much}$ more than other the qur'anic commentaries in regional language in Indonesia (Rohmana, 2013: 206). It is only a Javanese tafsir of which a number of publication may be much more than Malay, Sundanese, Acehnese, Buginese, and others (Gusmian, 2016: 141-68).

This study is significant to describe the problems of qur'anic commentaries in regional language in Indonesia. I will trace the historical background of the influence of modern qur'anic commentary in the Middle East, language policy of the Dutch colonial and the Indonesian government in the New Order period. It is a study that attempts to growing awareness that the study of qur'anic commentaries in regional languages in Indonesia does not merely reveal many peculiarities, such as the development of local tafsirs, the uniqueness of regional languages, and the integration of qur'anic commentaries into local creativity, in accordance with literary and cultural richness in Indonesia as studied by scholars in the later decades of the beginning of the early twentieth one century (Rohmana 2014: 79-99; Wahidi, 2015: 141-60; Baidowi, 2015: 33-61). However, it also describes the identity of local tafsirs that is increasingly declining due to the influence of internal and external elements in the study of the Qur'ān in Indonesia.

\section{Methods}

This study focuses on the opportunities and challenges of the Sundanese tafsir in the future, using social history and SWOT analysis. I use the social history analysis to examine the religion of Islam be approached from the development of intellectual tradition as a response to the previous thought to continue to exist in the history (Kuntowijoyo, 2003: 166-7). It is an analysis based on the argument that the history of Islam in Indonesia cannot be separated from the role of the publication of intellectual works, such as the qur'anic commentary in Sundanese. Previous studies on the history of Sundanese tafsir is the main source of the analysis. I use the historical data to describe the dynamics of Sundanese tafsir at the beginning of the twentieth century until now. The analysis uses the literacy tradition of qur'anic commentary, from oral and manuscript to print, from print to digital, from pegon to latin script, from Arabic to Sundanese and Indonesian (Ong, 2002).

\section{Discussion}

The Arabic language played a significant role in Muslim society all over the world. Arabic is considered as a sacred and prestigious language than other. It is understandable that Arabic is God's chosen language to convey revelation to His messenger, Muhammad (Federspiel, 1994: 41; Saeed, 2008: 120). In cases of diglossia, a prestigious literary variety of Arabic language is superposed on any vernacular dialects of the language, such as Jawi (Malay wrote in Arabic script) and pegon (Javanese or Sundanese wrote in Arabic script). Also, qur'anic commentary in Arabic is regarded as prominent tafsir than others (Zimmer, 2000: 31-65; Gusmian, 2003: 64). The religious works of qur'anic commentary in Arabic that written by the Arab scholars always been the standard source of qur'anic studies in Indonesia. Therefore, the author of respected qur'anic commentaries in Indonesian archipelago having studied with Arab scholars who wrote the work of $t a f s \bar{r} r$ in the Middle East.

However, the use of Arabic in religious works of tafsir then is challenged by national and regional languages, along with the widespread of Islam in the Muslim 
world. It is not all Muslims can understand Arabic, and there is no prohibition for anyone who is considered qualified to write a qur'anic commentary in their languages (al-Suyuthi, 1951: 180-1). Although qur'anic translations and commentaries in national and regional language was initially received some challenges due to the qualification of its author, eventually it can be accepted by Islamic scholars along with the widespread of Islam in Indonesian archipelago (Riddell, 2014: 3).

The literary tradition of the Qur'ān in West Java has lasted for a long time as can be seen in ancient qur'anic manuscripts (Nurtawab, 2016: 49-53). However, the beginning of the twentieth century can be regarded as the period that marked an increase of the publication of Sundanese tafsirs (Rohmana, 2013: 206). This is may caused by many factors. Firtsly, the influence of the Shafi'i school teachings that reject the translation of the Qur'ān and Sundanese tafsìr. Secondly, the policy of the Dutch colonial government that attempt to restrict the printing of Islamic literature and their efforts to revive the purity of Sundanese through the printing of Sundanese books in 1850 (Zimmer, 2000: 44; 2001: 55).

The rise of translation of the Qur'ān and Sundanese tafsìr that published in the 1930s related to the influence of ideas about Islamic reform in the Middle East, especially what became known as "Cairene reform" (Bluhm-Warn 1983: 35-42; Burhanudin, 2005: 9-26; 2007: 168). The discourse of Islamic reform then influenced the reformist-modernist Muslims in West Java. They used print technology and published Islamic books and magazines that contain criticisms against traditionalist Muslims (Noer, 1996: 97, 103).

It also marked a shift in the literacy tradition, from oral to print tradition. The oral tradition that is still dominated by the scribe of manuscripts through handwriting to write the religious works or kitabs at pesantren. Meanwhile, the tradition of print literature is dominated by reformist Muslims. Print culture both reinforces and transforms the effects of writing on thought and expression. Since the shift from oral to written speech is essentially a shift from sound to visual space, here the effects of print on the use of visual space can be the central, though not the only, focus of attention (Ong, 2002: 115). Hence, the Indonesianist scholars point out that the growth of reformist Muslim movements, such as Muhammadiyah and Persatuan Islam (Persis) can be regarded as an urban phenomena in Indonesia (Shihab, 1995: 165). It cannot be separated from the policy of the Dutch colonial government on ethical politics of education and Sundanese language including through improving the culture of printed literacy (Moriyama, 2000). It is understandable, reformist Muslims may take a significant role in improving the publication of Islamic books including the Sundanese tafsir in the 1930s.

Now, however, the publication of Sundanese tafsìr is beginning to decline. There are many factors contributed to the decreasing publication of Sundanese tafsir. Firstly, the government policy of unitary language since the period of what we call as Sumpah Pemuda on October 28, 1928, which awakened the consciousness of national unity. Secondly, the assumptions of more complex rules of regional language. Thirdly, the lower grade awareness of regional languages among Sundanese people. Fourthly, the insistence of international languages globally. Fifthly, the invasion of global television networks and the evolution of the internet and social media.

The policy of Indonesia government to use Bahasa Indonesia as the national language in the socio-religious activities as well as the insistence of international languages, make the speakers of regional language were pushed to speak Sundanese in their families in the rural areas (Sobarna, 2007: 14). There are not many pesantrens in West Java that use Sundanese as the language of qur'anic literacy teaching than ever 
before as seen in the tradition of ngalogat (Yahya, 2009). The tradition of qur'anic literacy teaching was taught by teachers who use the national language as language of teaching. It indirectly also affects the decline of readers of the Sundanese translation of the Qur'ān and Sundanese tafsìr. The identity of the Sundanese tafsìr is not only too weak to compete with the qur'anic commentaries in the Indonesian language but also unable to respond to the increasingly critical global trend of qur'anic commentary with the Western scholarly approach (Ichwan, 1999: 31). It is different with Sundanese tafsirs that published in the 1930s, which were written in response to the idea of Islamic reform in the Middle East.

\section{The identity of Sundanese tafsīr and global trend of qur'anic commentary}

With the above of the decline of the publication of Sundanese tafsir in recent times, there is something worried about the serious threat against the identity of the Sundanese tafsir $r$. It is the identity that related to the peculiarities of the characteristics of language and thought of Sundanese tafsirr, which were formed when making contact with qur'anic commentaries in Arabic and hence engaging the different character of Sundanese tafsir from other works of tafsìr in the Islamic world (Rohmana, 2014).

As both Muhsin (2008) who studied the Javanese tafsì and Ibrahim (2012) who studied Buginese tafsir , Rohmana (2014: 79-99) has previously described the identity of Sundanese tafsìr in West Java. The language peculiarities of Sundanese tafsìr, according to Rohmana, can be seen from the richness of Sundanese language and literature in that tafsir. Sundanese tafsir usually use language levels (undak usuk basa), proverb (babasan, paribasa, kecap-kecapan), and metrical verse in the form of dangding or guguritan (Rohmana, 2015: 25-55). The richness of Sundanese language could be found, for example, in Haji Hasan Mustapa's Qur'anul Adhimi (1937), Wiranatakoesoema's Soerat Al-Baqarah (n.y.) and Hasim's Ayat Suci Lenyepaneun (1994). While the peculiarities of Sundanese tafsir, it is not only can be seen from the locality of qur'anic commentary discourse, which dominated by local Sufi commentary, such as Hasan Mustapa's Qur'anul Adhimi (1937), but also social criticism of Sundanese tafsir to the socio-religious situation, such as of Ahmad Sanusi's Malja' al-Talibin (1931), Abdul Halim's Tafsier Soerat al-Ma'oen (1930), M. Romli-Midjaja's Nurul-Bajan (1966) and Hasim's Ayat Suci Lenyepaneun (1994). Therefore, although the social criticism is also can be found in almost all tafsir that published in the modern era in general, the identity of the Sundanese tafsir has increasingly found its context dealing with socio-religious discourse in a local region (Rohmana, 2017: 28). The identity of Sundanese tafsitr is formed by the uniqueness of Sundanese language and locality of the religious discourse in West Java.

As has already been explained above, there are many contributory factors related to something worried about a serious threat against the identity of the Sundanese tafsir along with the decline of its publication in recent times. The lower grade awareness of regional languages among Sundanese people, for example, had an impact on their reading interest of Sundanese works that began to decrease. Therefore, there are qur'anic commentators in Sundanese who do not have enough capabilities of Islamic knowledge and Sundanese language and literature. Their Sundanese language of tafsir look cold and flat and had only minimal peculiarities of Sundanese literature, and even more so tend to be much influenced by Indonesian (kamalayon). It was different from previous qur'anic commentators in the period of 1930s. We can find many peculiarities in the form of the richness of Sundanese language and literature, such as Hasan Mustapa's Qur'anul Adhimi (1937).

Also, the decline of the publication of Sundanese tafsir absolutely can be difficult 
for the qur'anic commentators to respond many contemporary issues. Therefore, it is difficult to expect that Sundanese tafsir could respond to the increasingly critical global trend of qur'anic commentary with the Western scholarly contemporary approach, such as ecology, human rights, terrorism, living Qur'ān, late antiquity, and others. This was different from previous qur'anic commentators in the period of 1930s who could respond many issues of a global trend of qur'anic commentary, such as the idea of Islamic reform in the Middle East.

The propagation of Muhammad 'Abduh's reformism in Egypt through the reform journals and qur'anic commentary, al-Manar, could gain influence over Muslim society in Malay-Indonesia, including Sundanese people in West Java. The qur'anic commentary of al- Manar also stimulated the growth of reformed Muslim society, the reformists, providing the Islamic reform movement with strong ideological support. The activist of Muhammadiyah, Persatuan Islam (Islamic union), and Persatuan Ummat Islam, then published some Sundanese tafsitrs to respond the idea of reformism. The works of Sanusi, Abdul Halim, Romli-Midjaja, Sanuci represented a global issue of Islamic reform in Sundanese tafsirs in the 1930s. It then continues to 1990s until now when Hasim and Suhendar published another reformist Sundanese tafsirs. It was published in Priangan areas, such as Bandung, Sukabumi, Garut and Tasikmalaya. It is interesting that we can also find the column of Sundanese tafsirs in Sundanese magazines, which published by the reformists in 1930s until now, such as At-Taqwa and Iber published by branch of Persatuan Islam Bandung and Bina Da'wah published by branch of Dewan Dakwah Islamiyah Indonesia (DDII) in West Java (Wildan, 2011).

\section{Strengths, weaknesses, opportunities, and threats}

As has already been explained above, there is something worried about a serious threat against the identity of Sundanese tafsir along with the decline of its publication in recent times. Therefore, it is important to analyze the opportunities and challenges of Sundanese tafsir in the future, using SWOT analysis. It is used to highlights the strengths, weaknesses, opportunities, and threats of Sundanese tafsir . As a result, it can be taken into consideration in improving the existence Sundanese tafsir in the future.

Sundanese tafsir has the strength seen from the uniqueness of its language that is much richer than Indonesian tafsir , such as Sundanese language levels and proverbs. In addition, although the social criticism is also can be found in almost all tafsir that published in the modern era in general, the identity of the Sundanese tafsir has increasingly found its context dealing with socio-religious discourse in the local region.

Unfortunately, the richness of language in Sundanese tafsir is also can be a weakness at the same time for the reader, especially among Sundanese young people. They think Sundanese is more complicated language than Indonesian. Therefore, they chose to read the qur'anic commentaries in Bahasa Indonesia, because it belongs the same content of tafsir. Also, the decline of Sundanese speakers in the urban area led to make many readers and publishers of Sundanese tafsir in West Java also begin to decline.

However, the increasing role of Islam in religious life at the end of the twentieth century could be an opportunity to strengthen the study of Qur'ān in the local regions. There are also many qur'anic print publishers that succeed to commercialise the qur'anic print in Indonesia. It shows the growing of Muslim interest to learn the Qur'ān and its tafsir. Also, the issue of regional autonomy in Indonesia that had strengthened after 1998 could also be a momentum to reinforce the use of Sundanese in qur'anic learning and commentary. Although it may not be ignored that some scholars worried 
about the serious threat of primordialism that smashes the egalitarian principles of democracy in Indonesia.

Finally, the rise of a religious program on television and social media can be an opportunity as well as a threat to the literacy culture, including the publication of Sundanese tafsir . It can facilitate the discourse of tafsitr to reach wider audiences with an opportunities to come into online media. It is also important to consider the work of unwritten tafsir as can be seen from religious program show on television. However the television program and social media, on the contrary, indirectly threat the print culture of Sundanese tafsìr. It becomes a strong marker of improved literacy culture in Muslim society than it restores society to their oral cultures. The Sundanese publishers including the publisher of Sundanese tafsitr are beginning to decline. It is important to consider the Sundanese tafsir program on regional television or social media, such as the program of "Tafsir al-Mishbah" by M. Quraish Shihab on television or fan page of social media (facebook, twitter, whatsup, etc.), such as the fan page of qur'anic commentary of "Salman Harun" and others (Feener, 1998: 76; Lukman, 2016: 120-1). Also, the policy of national language that unites the national identity has a major impact on the development of regional languages in Indonesia, including the development of the study of the Qur'ān in West Java.

\section{Conclusion}

This study highlights the opportunities and challenges of qur'anic commentaries or tafsitr in Sundanese. Sundanese tafsitr, like other local or regional tafsir , was circulated in limited publication, in line with limited readers. Although the publication of Sundanese tafsir is known quite a lot than other regional tafsir in Indonesia, socio-religious changes will also determine the position of the tafsir in the future. Fifteen years before the independent day in 1945 became an important period of increasing publications of religious works including Sundanese tafsir in Indonesia. It happened along with strengthening of the modernist-reformist movements and traditionalist responses through the work of Sundanese tafsìr. Some Sundanese tafsir also appeared and received positive responses among Sundanese readers at the end of the twentieth century.

It was not only related to the previous issue of the Islamic reform in the Middle East, but also cannot separated from other factors, such as strengthening the regional identity in the form of regional autonomy program in Indonesia, the nature of Sundanese open culture, their awarenesses of Sundanese as a mother language and language of sense, and the religiosity of Sundanese people that increase to show the symbol of Islam in public sphere during the last three decades. These factors would be an opportunity to develop the Sundanese tafsir and other local qur'anic commentaries in Indonesia.

However, these opportunities cannot be separated from challenges faced by local qur'anic commentaries in West Java and other regional areas. These are challenges that may become serious threats or otherwise new opportunities for Islamic scholars who studied the local qur'anic commentaries in Indonesia. There are many challenges would be faced by Sundanese tafsir in the future, such as the dynamics of Sundanese culture and Islamic religion, the decline of Sundanese speakers, the infiltration of national and foreign languages, the evolution of communication technology, and many national and global issues (human rights, ecology, disasters, terrorism, poverty and others).

The author of Sundanese tafsirs, as well as other local tafsìr in Indonesia, have to consider some efforts to row the opportunities and challenges. They, on the 
one hand, must be aware of the limitations of its readers, but on the other hand, they need to respond to more broader issues. Sundanese tafsir can no longer be written only to respond to the local and regional issues, but also develop a n appropriate method, and content of tafsir $r$ s correspond to the dynamics of Muslim society in the world.

\section{References}

Baidowi, Ahmad. 2015. “Aspek Lokalitas Tafsir Al-Iklīl F̄̄ Ma'ān̄i Al-Tanzīl Karya KH Mishbah Musthafa," Nun Jurnal Studi Alqur'an dan Tafsir di Nusantara, Vol. 1, No. 1, 33-61.

Bluhm-Warn, Jutta. 1983. "A Preliminary Statement on the Dialogue Established between the Reform Magazine Al-Manar and the Malay-Indonesian World," Indonesia Circle, No. 32, 35-42.

Burhanudin, Jajat. 2005. "Aspiring for Islamic Reform: Southeast Asian Requests for Fatwas in Al-Manar," Islamic Law and Society, Vol. 12/1, 9-26.

2007. "Islamic Knowledge, Authority and Political Power: The "Ulama in Colonial Indonesia," Ph.D. Dissertation, Leiden University.

Chalim, Abdul. 1930. Tafsier Soerat Al-Ma'oen, Madjalengka: Drukkerij "Sederhana."

Federspiel, Howard M. 1994. Popular Indonesia Literature of the Qur'an, Ithaca, New York: Cornell Modern Indonesia Project.

Feener, R. Michael. 1998. "Note towards the History of Qur'anic Exegesis in Southeast Asia," Studia Islamika, Vol. 5, No. 3.

Gusmian, Islah. 2003. Khazanah Tafsir Indonesia, dari hermeneutika hingga Ideologi, Bandung: Mizan.

-------. 2016. "Tafsir Al-Qur'an Bahasa Jawa: Peneguhan Identitas, Ideologi, dan Politik," Suhuf, Vo. 9, No. 1, 141-168.

Hasim, Moh. E. 1994. Ayat Suci Lenyepaneun, Bandung: Pustaka.

Ichwan, Moch. Nur. 1999. A New Horizon in Qur'anic Hermeneutics: Nasr Hamid Abu Zayd's Contribution to Critical Qur'anic Scholarship, Thesis submitted to the Faculties of Theology and Arts of Leiden University, Leiden University, The Netherlands.

Ibrahim, Sulaiman. 2012. Tafsir Al-Qur'an Bahasa Bugis: Vernakularisasi dalam Kajian Tafsir al-Munir, Disertasi, Jakarta: UIN Syarif Hidayatullah.

Kuntowijoyo. 2003. Metodologi Sejarah, Edisi Kedua, Yogyakarta: PT. Tiara Wacana, 2003.

Lukman, Fadhli. 2016. "Tafsir Sosial Media di Indonesia," Nun, Jurnal Studi Alquran dan Tafsir di Nusantara, Vol. 2, No. 2.

Moriyama, Mikihiro. 2000. "Moehamad Moesa, print literacy, and the new formation of knowledge in nineteenth-century West Java," Indonesia and the Malay World, 28:80, 5-21, DOI: 10.1080/13639810050006503

Muhsin, Imam. 2008. Tafsir Al-Qur'an dan Budaya Lokal: Nilai-nilai Budaya Jawa dalam Tafsir Al-Huda Karya Bakri Syahid, Disertasi, Yogyakarta: UIN Sunan Kalijaga.

Mustapa, Haji Hasan. 1937. Petikan Qoer'an Katoet Adab Padikana, diurus djeung diatur ku Comite Mendakna, Bandung: Droek Boehron Bd.

Noer, Deliar. 1996. Gerakan Moderen Islam di Indonesia 1900-1942, Jakarta: LP3ES.

Nurtawab, Ervan. 2016. "Qur'anic translations in Malay, Javanese and Sundanese: a commentary or substitution?," in Majid Daneshgar, Peter G. Riddell and Andrew Rippin, The Qur'an in the Malay-Indonesian World, London and New York: Routledge.

Ong, Walter J. 2002. Orality and Literacy: The Technologizing of the World, London 
and New York: Routledge.

Rafiq, Ahmad. 2014. "The Reception of the Qur'an in Indonesia: A Case Study of the Place of the Qur'an in a Non-Arabic Speaking Community," Diseertation, The Temple University.

Riddell, Peter G. 2014. "Translating the Qur'ān into Indonesian Languages," Al-BayanJournal of Qur'an and Hadith Studies 12, 1-27.

Rohmana, Jajang A. 2013 "Perkembangan Kajian Al-Qur'an di tatar Sunda: Sebuah Penelusuran Awal," Jurnal Suhuf, Vol. 6 No. 1, 197-224.

------. 2014. "Memahami Al-Qur'an dengan Kearifan Lokal: Nuansa Budaya Sunda dalam Tafsir Al-Qur'an Berbahasa Sunda," Journal of Qur'an and Hadith Studies - Vol. 3, No. 1, 79-99.

-------. 2015. "Ekspresi Lokalitas Tafsir Sufistik di Tatar Sunda: Qur'anul Adhimi Aji Wiwitan Kitab Suci Haji Hasan Mustapa (1852-1930), Al-Qalam, Vol. 32, No. 1, 25-55.

-------. 2017. "Polemik Keagamaan dalam Tafsir Malja' al-Talibin Karya KH. Ahmad Sanusi," Suhuf, Vol. 10, No. 1.

Romli, Mhd. dan H.N.S. Midjaja. 1966. Nurul-Bajan: Tafsir Qur'an Basa Sunda. Jilid 13. Bandung: N.V. Perboe. Cet. ke-2.

Saeed, Abdullah. 2008. The Qur'an, an Introduction, London and New York: Routledge.

Sanusi, Ahmad. 1931. Malja' al-Thâlibîn, Tapsir bahasa Soenda, No 8. Tanah Tinggi Senen No. 191 Batavia Kramat.

Sardar, Ziauddin. 1983. "The Future of Islamic Studies, " Islamic Culture 57.

Shihab, Alwi. 1995. "The Muhammadiyah Movement and Its Controversy with Christian Mission in Indonesia," Ph.D. Dissertation, The Temple University.

Sobarna, Cece. 2007. "Bahasa Sunda Sudah di Ambang Pintu Kematiankah?," Makara Sosial Humaniora, Vo. 11, No. 1.

Stearns, Peter N. (ed.), 1994. Encyclopedia of Social History. New York \& London: Garland Publishing Inc.

Suhendar, Uu. 2011. Tafsir Al-Razi Juz 'Amma jeung Al-Fatihah, Kasaluyuan Surat, Ayat jeung Mufrodat, Tasikmalaya: Pustaka Al-Razi.

Suryadinata, Leo. 2003. Indonesia's Population: Ethnicity and Religion in a Changing Political Landscape, Singapore: Institute of Southeast Asian Studies (ISEAS).

Al-Suyuthi, Jalaluddin. 1951. Al-Itqan fi 'Ulum al-Qur'an, Beirut: Dar al-Fikr.

Wahidi, Ridhoul. 2015. "Hierarki Bahasa dalam Tafsir Al-Ibrìz li Ma'rifah Tafsìr AlQur'ān al-'Azìz Karya K. H. Bisri Musthofa, Suhuf, Volume 8, No. 1, 141-160.

Wildan, Dadan. 2011. "Pergulatan Persatuan Islam (Persis) dalam Dakwah di tatar Sunda (Kajian terhadap Majalah Sunda "Iber" sebagai Media Dakwah Berbahasa Sunda)," Konferensi Internasional Budaya Sunda II, Bandung 19-22 November.

Wiranatakoesoema, R.A.A. (n.y.). Soerat Al-Baqarah: Tafsir Soenda damelan AlHadji R.A.A. Wiranatakoesoemah Bandung: "Poesaka."

Yahya, Iip Zulkifli. 2009. "Ngalogat di Pesantren Sunda: Menghadirkan yang Dimangkirkan", in Henri Chambert-Loir (ed.), Sadur, Sejarah Terjemahan di Indonesia dan Malaysia, Jakarta: KPG.

Zimmer, Benjamin G. 2000. "Al-'Arabiyyah and Basa Sunda: Ideologies of Translation and Interpretation among the Muslims of West Java", Studia Islamika, 7 (3), 3165 . 2001. "Purisme Bahasa Sunda dan Bahasa Indonesia dalam Sejarah Kolonial dan Pascakolonial," Dangiang. July. 